Nova Southeastern University

Florida

NSUWorks

Faculty Scholarship

Shepard Broad College of Law

$1-1-2010$

\title{
John B. West: Founder of the West Publishing Company
}

Robert M. Jarvis

Follow this and additional works at: https://nsuworks.nova.edu/law_facarticles

\section{Recommended Citation}

Robert Jarvis, John B. West: Founder of the West Publishing Company, 50 American Journal of Legal History 1 (2010).

This Article is brought to you for free and open access by the Shepard Broad College of Law at NSUWorks. It has been accepted for inclusion in Faculty Scholarship by an authorized administrator of NSUWorks. For more information, please contact nsuworks@nova.edu. 


\section{HEINONLINE}

DATE DOWNLOADED: Mon Nov 23 11:14:17 2020

SOURCE: Content Downloaded from HeinOnline

Citations:

Bluebook 21st ed.

Robert M. Jarvis, John B. West: Founder of the West Publishing Company, 50 AM. J. LEGAL Hist. 1 (2008).

ALWD 6th ed.

Jarvis, R. M., John b. west: Founder of the west publishing company, 50(1) Am. J.

Legal Hist. 1 (2008).

APA 7th ed.

Jarvis, R. M. (2008). John b. west: Founder of the west publishing company. American Journal of Legal History, 50(1), 1-22.

Chicago 7th ed.

Robert M. Jarvis, "John B. West: Founder of the West Publishing Company," American Journal of Legal History 50, no. 1 (January 2008-2010): 1-22

McGill Guide 9th ed.

Robert M Jarvis, "John B. West: Founder of the West Publishing Company" (2008) 50:1 Am J Leg Hist 1.

MLA 8th ed.

Jarvis, Robert M. "John B. West: Founder of the West Publishing Company." American Journal of Legal History, vol. 50, no. 1, January 2008-2010, p. 1-22. HeinOnline.

OSCOLA 4th ed.

Robert M Jarvis, 'John B. West: Founder of the West Publishing Company' (2008) 50 Am $\mathrm{J}$ Legal Hist 1

Provided by:

NSU Shepard Broad College of Law Panza Maurer Law Library

-- Your use of this HeinOnline PDF indicates your acceptance of HeinOnline's Terms and Conditions of the license agreement available at https://heinonline.org/HOL/License

-- The search text of this PDF is generated from uncorrected OCR text.

-- To obtain permission to use this article beyond the scope of your license, please use: Copyright Information 


\title{
John B. West: Founder of the West Publishing Company
}

\author{
by ROBERT M. JARVIS*
}

\section{I \\ INTRODUCTION}

In the Spring 1982 issue of the Law Library Journal, an unidentified reader, channeling Virginia O'Hanlon (the little girl who wanted to know if Santa Claus was real), innocently inquired, "Was there a man named West in the West Publishing Company?"1 The Journal's response, although not nearly as elegant as Francis P. Church's answer to Virginia, ${ }^{2}$ was just as emphatic:

Yes. John B. West, the founder of West Publishing Company, wrote an article in the Law Library Journal [in 1909]. He began dealing with lawyers in 1874 and realized that there was [a] multiplicity of reports published in both official and unofficial form and in journals. Advances in typesetting machines made it easy to

* Professor of Law, Nova Southeastern University (jarvisb@nsu.law.nova.edu). B.A., Northwestern University; J.D., University of Pennsylvania; LL.M., New York University. The preparation of this essay would have been impossible without the assistance of three talented genealogists: Linda B. Coffin (www.historycrafters.com) in Minneapolis, Minnesota; Darlene C. Joyce, CG (www.findmyfamilyplease.com) in St. Paul, Minnesota; and Alice C. Volkert (www.volkertservices.com) in Costa Mesa, California. I also received invaluable help from Mrs. Mary D. Baker and Dr. Donald M. West, two of John B. West's grandchildren, as well as the following individuals: Jana Armstead, Research Manager, Ramsey County (Minnesota) Historical Society; G. Burnham Atterbury, Assistant Dean-Law School Development, University of San Francisco; Mary Bakeman, Proprietor, Park Genealogical Books; Robert C. Berring, Jr., Walter Perry Johnson Professor of Law, University of California-Berkeley; Gretchen DeSutter, Senior Communications Specialist, Thomson West; Jennifer Fauxsmith, Reference Archivist, Massachusetts Archives; Michelle Gachette, Reference Assistant, Harvard University Archives; Yvonne Hasegawa, Technical Specialist, Pasadena Public Library; Don L. Hofsommer, Professor of History, St. Cloud State University; Karen Klinkenberg, Library Assistant, University of Minnesota Archives; Christina R. Lehman, Assistant Archivist, National Society Daughters of the American Revolution; William P. Logan, Reference Librarian, Santa Clara University Law Library; Jamie Murray, Information Services Coordinator, Brazoria County (Texas) Historical Museum; Brent T. Peterson, Executive Director, Washington County (Minnesota) Historical Society; Nancy Salisbury, Archival Assistant-Pioneer Room, Escondido Public Library; Joan K. Sansbury, Librarian/Curator, The Supreme Council-Ancient \& Accepted Scottish Rite, Southern Jurisdiction, U.S.A.; Peter Steelquist, Past President, San Diego Genealogical Society; Nanci A. Young, Archivist, Smith College. As usual, I am indebted to the hardworking staff of the Nova Southeastern University Law Library, particularly Rob Hudson, Meg Kribble, and Maxine Scheffler. Lastly, I acknowledge with deep appreciation the generous financial support extended by Deans Joseph D. Harbaugh and Lisa A. Smith-Butler.

The research contained herein is current as of April 15, 2008.

1. John W. Heckel, Questions and Answers, 75 LAw LiBR. J. 299, 305 (1982).

2. See Is There a Santa Claus?, THE SuN (New York), Sept. 21, 1897, at 1. Although the editorial was unsigned, Church's authorship was revealed after his death in 1906. See Murray Illson, Letter to The Sun, N.Y. Times, May 14, 1971, at 44. 


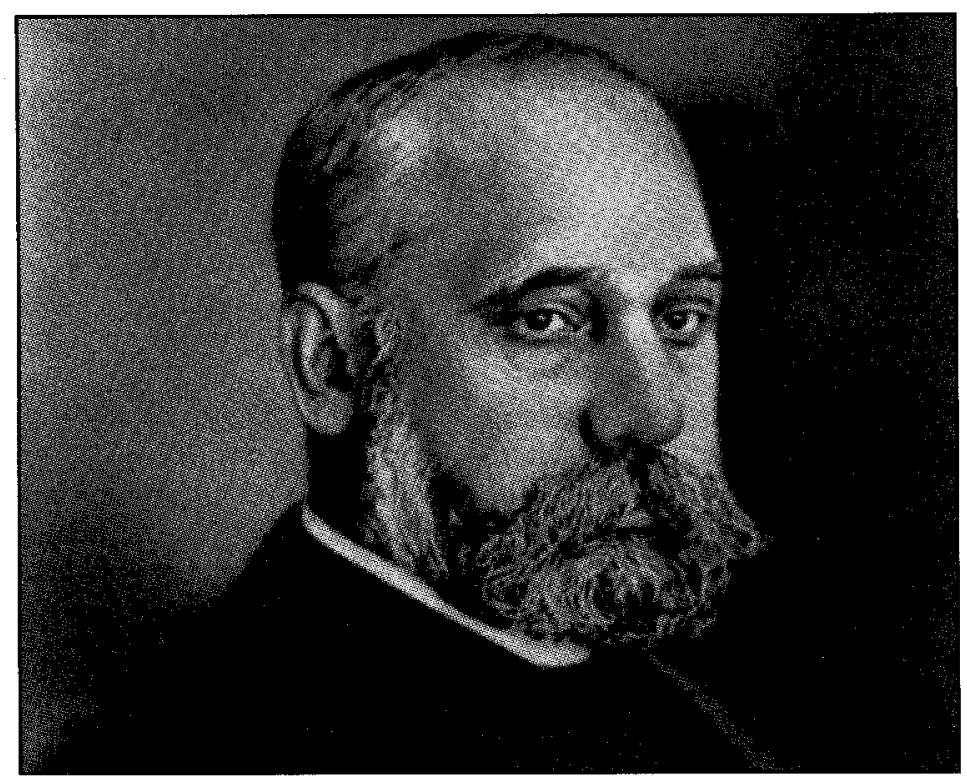

John B. West (1852-1922)

Founder of the West Publishing Company

publish unofficial current court opinions and to have fewer and simpler reports. In 1876 he began to publish the North Western Reporter in paperback to furnish the local practitioners with copies of all new decisions promptly and cheaply so they could avoid buying certified copies. It became evident to him that a syllabus was needed, and in 1879 West began to publish the American Digest System with key numbers. ${ }^{3}$

That the question needed to be asked, and that the answer was so brief (yet made a complete hash of the few facts it did include), reflects an interesting duality: despite all that he did in life, in death John B. West has become a forgotten man, ignored by the company that bears his name and all but unknown in the profession he single-handedly revolutionized.

\section{II \\ JOHN BEFORE WEST}

John Briggs West was born on August 6, 1852, in Roxbury, Massachusetts. ${ }^{4}$ His father was William C. West (1818-1904), 5 a book-

3. Heckel, supra note 1, at 305 (footnote omitted).

4. Little Sketches of Big Folks: An Alphabetical List of Representative Men of Minnesota with Blographical Sketches 420 (1907); Massachusetts Archives, Vital Records Search-Birth Records, http://www.sec.state.ma.us/vitalrecordssearch/ VitalRecordsSearch.aspx (last visited Apr. 15, 2008) (at Volume 64, Page 223).

5. William C. West Dies, St. Paul Proneer Press, Feb. 8, 1904, at 2; Ramsey County (Minn.) Death Card for William C. West (No. 1904-38-1290), Feb. 7, 1904 (copy on file with the author). 
keeper who hailed from Concord, New Hampshire, 6 and his mother was Louisa P. Briggs (1816-1905), 7 a native of Salem, Massachusetts, whose maternal grandfather, Stephen Jones, had been a sergeant in that colony's militia during the Revolutionary War. 8

John's parents married in Boston in $1843,{ }^{9}$ and by the time of his birth they had two children: Louisa (1844-1927)10 and Horatio (18481936). 11 Later, two more girls would come along: Lillian (called Lillie) (1853-1923)12 and Fannie (1856-77). ${ }^{13}$ Three other siblings, for whom no records exist, died either in childbirth or early infancy. 14 Although not rich, the Wests were comfortable, and the 1860 federal census noted they had a 26-year-old live-in maid named Sarah Mooney. 15

John initially was educated in Roxbury, but when his family moved north to the nearby town of Malden, he attended its schools. 16 He was an avid reader and had a passion for sports, but in a diary recounted his struggle to master Latin. 17 It appears he got only as far as the eighth grade, for

6. William West \& Mary Barker, http://www.illian.org/places/FamilySheets/d0010/ F134367.html\#1356959 (last visited Apr. 15, 2008) (under "Children: William Carter West").

7. Funeral This Afternoon-Mrs. Louisa P. West Dies at Residence, 653 Grand Avenue, St. Paul Pioneer Press, Dec. 12, 1905, at 3; Ramsey County (Minn.) Death Card for Louisa P. West (No. 1905-44-2484), Dec. 10, 1905 (copy on file with the author).

8. II National Society Daughters of the American Revolution, DaR Patriot INDEX 1490 (2003).

9. Nancy Bolger Lasko, West, William Carter b. 2/15/1818, N.H., http://genforum. genealogy.com/west/messages/380.html (last visited Apr. 15, 2008).

10. West, Louisa, L.A. TIMES, Aug. 4, 1927, at 22; Washington State Board of HealthBureau of Vital Statistics, Certificate of Death for Louisa Briggs West, Aug. 3, 1927 (copy on file with the author).

11. Horatio D. West-Dies at 88, St. Paul Pioneer Press, Feb. 19, 1936, at 6; West, Horatio, L.A. Times, Mar. 3, 1936, at A18; Washington State Board of Health-Bureau of Vital Statistics, Certificate of Death for Horatio Davis West, Feb. 16, 1936 (copy on file with the author).

12. St. Paul Pioneer Dies; Mrs. Lillie West Marvin Succumbs to Paralytic Stroke, ST. Paul Pioneer Press, Aug. 28, 1923, at 11; State of Minnesota-Division of Vital Statistics, Certificate of Death for Lillie West Marvin, Aug. 26, 1923 (copy on file with the author).

13. 3 Oakland Cemetery Records, St. Paul, Minnesota-1 June 1871-31 May 1878 , at 75 (Sharon Bruckner ed., 1991) (indicating that Fannie West died at the age of $201 / 2$ from "Febris hectica," which suggests she had tuberculosis); http://www.dalbydata.com/ user.php?action=cemsearchresults (last visited Apr. 15, 2008) (listing her date of death as February 5, 1877).

14. Office of the Secretary of the Interior, The Twelfth Census of the United STATES: 1900 (1902) (Line 62 of Schedule No. 1.-Population of the State of Minnesota, County of Ramsey, Ward of City 7, enumerated June 7, 1900) (copy on file with the author).

15. Office of the Secretary of the Interior, The Eighth Census of the United STATES: 1860 (1864) (Line 21 of Schedule 1.-Free Inhabitants in Ward 4, City of Roxbury, in the County of Norfolk, State [sic] of Massachusetts, enumerated June 12,1860) (copy on file with the author).

16. William W. Marvin, West Publishing Company: Origin, Growth, Leadership 24 (1969).

17. Id. 
in 1867 he went to work in Boston. ${ }^{18}$ By the time he was 17 , he was employed as a grocery clerk. 19

In 1870, William West was named paymaster of the Lake Superior \& Mississippi Railroad Company, headquartered in St. Paul, Minnesota.20 Founded in 1857 as the Nebraska \& Lake Superior Railroad Company, its launch had been delayed by frequent ownership changes, a political scandal, and the Civil War.21 Now, however, it was ready to bring flour and grain to the lake, coal and salt to the river, and a boom to Duluth, its northern terminus. 22

It is unclear how the railroad came to be in touch with William. Regardless, his decision to accept the job meant moving halfway across the country. This relocation actually served to reunite his brood, for Horatio, John's older brother, already was in Minnesota, working as a hired hand on a farm owned by Julia and William Munger in the St. Paul suburb of Cottage Grove.23 The Mungers were two of the town's earliest settlers, having arrived in 1851.24

Once in St. Paul, John quickly landed an outside sales job with the D.D. Merrill Book Store,25 which had started as a notions shop in a log cabin in 1851.26 In his new position, John traveled to border towns along the Mississippi River, taking orders for furniture, general office supplies, stationery, and, as a sideline, legal and medical books. 27

18. LiTTLE SKETCHES, supra note 4 , at 420.

19. Office of the Secretary of the Interior, The Ninth Census of the United STATES: 1870 (1872) (Line 27 of Schedule 1.- Inhabitants in Malden, in the County of Middlesex, State [sic] of Massachusetts, enumerated June 14, 1870) (copy on file with the author).

20. MARvin, supra note 16 , at 25 . The job of paymaster was an important one, and required both accounting skills and scrupulous honesty:

Railroad companies during the 1870s had very few general officers, and even these had multiple tasks-Secretary \& Treasurer, as an example. A paymaster would not have been one of these, but he would have been an officer, a mid-level manager, not a clerk, likely an immediate subordinate under the company treasurer. In 1870, LS\&M's treasurer was in Philadelphia, so the paymaster in St. Paul may have been "number one" or "number two" on the local scene.... The paymaster in those days boarded "the pay car" and went up and down the line "paying" employees at all levels.

Letter from Don L. Hofsommer, Professor of History, St. Cloud State University, to the author, dated Feb. 18, 2008 (copy on file with the author).

21. W.H.C. Folsom, FifTy YeARS IN THE NORTHWEST 668-69 (1888).

22. Don L. Hofsommer, Minneapolis and the Age of Rallways 32, 60 (2005). Although the line did not officially open until September 15, 1870, on August 1st a special train carrying Chief Justice Salmon P. Chase toured its tracks. Id. at 32.

23. NinTh Census, supra note 19 (Line 3 of Schedule 1.- Inhabitants in Cottage Grove, in the County of Washington, State of Minnesota, enumerated July 12, 1870) (copy on file with the author).

24. Brent Peterson, The Dying Family Farm-Munger Farm of Cottage Grove, HistoriCAL WhiSPERINGS, Apr. 2004, at 1, available at http://www.wchsmn.org/content 2004/05/munger/ (last visited Apr. 15, 2008).

25. MARviN, supra note 16 , at 26.

26. Kevin Galvin, The Necessities of Life-Available Early on the Frontier, 11 RAMSEY COUNTY Hist. 8, 10 (Fall 1974).

27. MARVIN, supra note 16 , at 26. 
Many of the customers John called on were lawyers, and all of them complained about the hardships of running a frontier practice. 28 Recognizing an opportunity, in 1872 John quit his job at Merrill and set up his own agency, styled "John B. West, Publisher and Book Seller," in rented space at 60 West Third Street.29

From the outset, John focused on servicing the bar. He created a line of legal forms, reprinted hard-to-find treatises, and produced a muchneeded index to the Minnesota statutes. $30 \mathrm{He}$ also arranged to have the state's rules of practice translated into Swedish, an effort that was much appreciated by the region's many Scandinavian-born lawyers and judges. 31

In 1875 , John was still single and living with his parents in their home at 171 Pleasant Avenue. 32 So, too, was his brother Horatio, who had become a bookkeeper at Mayo \& Clark, a local hardware supplier. ${ }^{33}$ In May, however, Horatio got married. ${ }^{34}$ Soon, there would be even bigger changes.

\section{III \\ JOHN AT WEST}

In 1876, with his business booming, John persuaded Horatio to become his partner. 35 From the outset, the pair complemented each other:

The two West brothers were a good balance as business associates for the pioneer days. John, the younger brother and founder of the business, was a decisive pushing character, impatient to put into effect expansion plans and a most persuasive salesman, mentally alert and physically robust (the author recalls that he played a good game of handball until he was near 60 years of age)....

Horatio West, in many respects, was John's opposite, with a cautious temperament and a weak physical stature, caused in part by a serious illness in his boyhood and a fall that permanently weakened his back. . . . His prudence was a counterbalance to John's lack of interest in detail or in fiscal matters, and was therefore of great importance to the young, struggling company. ...36

28. Id. at 26-27.

29. Id. at 27-28. John's decision to locate his new business on Third Street (renamed Kellogg Boulevard in 1929) was a shrewd one, for it placed him in the heart of the city's business district. See Virginia Huck, The Many Worlds of Homer P. Clark 112 (1980); Kellogg Boulevard: The Story of Old Third Street, 6 RAMSEY CoUnTY Hist. 14 (Fall 1969).

30. MARVIN, supra note 16, at 28-29.

31. Id. at 29.

32. St. Paul City Directory for 1875, at 420 (1875) [hereinafter cited as 1875 DIRECTORY].

33. Id.

34. See Massachusetts Archives, Vital Records Search-Marriage Records, http://www. sec.state.ma.us/vitalrecordssearch/VitalRecordsSearch.aspx (last visited Apr. 15, 2008) (indicating, at Volume 272, Page 131, that Horatio married Eliza A. Barney in Malden).

35. MARVIN, supra note 16 , at 30,32 .

36. Id. at 54-55. Elsewhere in his narrative, Marvin describes John as "an optimistic, buoyant and enthusiastic personage who had a way of convincing those whom he contacted." Id. at 90 . For pictures of the pair, see id. at 5 (John) and 7 (Horatio). 
Shortly after teaming up, John and Horatio began publishing an eight-page weekly they dubbed The Syllabi. As the first issue explained, its purpose was to provide lawyers with a cheap and efficient means for learning about new cases:

The syllabi of the decisions of the Supreme Court of Minnesota have heretofore appeared in the daily papers only as it happened to suit the convenience of a reporter, or when a scarcity of news made them useful in filling up space, sometimes being in one paper, and sometimes in another.

It has been a matter of much annoyance to the attorneys of our State that these decisions have not been published regularly in some one paper, immediately after being filed, and well knowing the importance of such a publication to the profession, we propose issuing the "Syllabi."

It will contain the syllabus, (prepared by the Judge, writing the opinion,) of each decision of the Supreme Court of Minnesota, as soon after the same is filed as may be practicable, accompanied, when desirable to a proper understanding of the points decided, with an abstract of the case itself, and when the decision is one of general interest and importance, with the full opinion of the Court.

It will also contain abstracts of, and opinions in the more important decisions in the United States Courts of Minnesota, as well as those of particular interest decided in the several District Courts of the State. The general design being to furnish the legal profession of the State, with prompt and reliable intelligence as to the various questions adjudicated by our own Courts, and at a date long prior to the publication of the regular reports.

It is not our purpose to confine our attention exclusively to reports from our own State, but while making those first in importance, also to furnish digests or opinions in cases decided in other States, which may have a special importance here or be of more than general interest. 37

The experiment proved an immediate hit, and in 1877 it was renamed the North Western Reporter with expanded Wisconsin coverage.38 In 1879, this gave way to a new North Western Reporter (covering the supreme courts of Iowa, Michigan, Minnesota, Nebraska, Wisconsin, and the Dakota Territory), the first of the West regional reporters and the cornerstone of its National Reporter System. 39

Although both he and Horatio had their hands in full,40 it was during this period that John got married. 41 His bride was a local school teacher

37. The Syllabi, Oct. 21, 1876, at 1, reprinted in Marvin, supra note 16, at 31 .

38. MARVIN, supra note 16, at 36-37.

39. Id. at 38,46 .

40 . $I d$. at $52-53$ (" $[\mathrm{T}]$ he two brothers ... were literally 'working around the clock' to publish 'The Syllabi' promptly, to contact advertisers and to handle the many and varied tasks that must daily be completed to keep the shop going. . . . John West was out in the territory a considerable part of the time either obtaining or arranging for manuscript copy from the several courts, soliciting advertising or on a general sales trip. Horatio kept the books and also handled collections. ...").

41. Exactly when and where John got married is unknown. See E-mail from Darlene C. Joyce, CG, Principal, www.findmyfamilyplease.com, to the author, Apr. 13, 2008, 3:59 p.m. (copy on file with the author) (listing the numerous steps taken by her to try to determine the actual date, all to no avail), and E-mail from Linda B. Coffin, Principal, www.historycrafters.com, to the author, May 12, 2008, 5:19 p.m. (copy on file with the author) (same). 
named Lillian B. Bronson (1854-1936), 42 who had been born in Williamsport, Pennsylvania, and was a descendant of Asa Bronson, a private in the Connecticut Volunteers in the Revolutionary War. 43 In time, the couple would have five children: Louise (1880-1966), 44 John Jr. (1883-1912), 45 Donald (1884-1974),46 Katherine (1886-1961),47 and Bronson (1889-1950),48

Needing capital to expand, in 1882 the brothers decided to take in two investors. Thus, what had been a partnership now became a corporation known as the West Publishing Company, with John as president, Horatio as treasurer, (Jesse) Peyton Boyle as secretary, and Charles W. Ames as the fourth stockholder. ${ }^{49}$ This was a happy time for John, who in

42. 74 National Society of the Daughters of the American Revolution, Lineage BOoK 158 (Mae Johns ed., 1924); 1875 DiRECTORY, supra note 32, at 121 (listing Lillian as a teacher at the Jefferson School); West, Mrs. Lillian Bronson, PASAdENA STAR NEws, May 30 , 1936, at 2; State of California-Department of Public Health, Certificate of Death for Lillian Bronson West, May 30, 1936 (copy on file with the author).

43. I DAR Patriot IndeX, supra note 8, at 344; MEMORIal ReCORd of the NoRTHERN Peninsula of Michigan 170 (1895); Lillian Bronson West-Application for Membership to the National Society of the Daughters of the American Revolution, Apr. 19, 1909 (copy on file with the author).

44. State of California-Department of Public Health, Certificate of Death for Louise Bronson West, Feb. 24, 1966 (copy on file with the author). Louise died in San Diego, although a search of that city's newspapers turns up no record of her death. See E-mail from Peter Steelquist, Past President, San Diego Genealogical Society, to the author, Mar. 20, 2008, 2:38 p.m. (copy on file with the author).

45. John B. West, Jr., Dies, St. Paul Pioneer Press, Sept. 4, 1912, at 14; State of Minnesota, Certificate of Death for John B. West, Jr., Sept. 3, 1912 (copy on file with the author).

46. State of California-Department of Health, Certificate of Death for Donald West, Nov. 16, 1974 (copy on file with the author). Donald's passing apparently went unnoticed by the local press. See E-mail from Alice C. Volkert, Principal, Volkert Services, to the author, Apr. 14, 2008, 8:27 p.m. (copy on file with the author) (finding nothing in the Los Angeles Times), and E-mail from Yvonne Hasegawa, Technical Specialist, Pasadena Public Library, to the author, Apr. 21, 2008, 8:46 p.m. (copy on file with the author) (finding nothing in the Pasadena Star News).

47. State of California-Department of Public Health, Certificate of Death for Katherine West, June 21, 1961 (copy on file with the author). Like her sister, Katherine died in San Diego without an obituary. See Steelquist E-mail, supra note 44.

48. Bronson West Dies; Was Head of Ad Firm, St. Paul Pioneer Press, Sept. 25, 1950 , at 14; Minnesota Department of Health-Division of Vital Statistics, Certificate of Death for Bronson West, Sept. 24, 1950 (copy on file with the author).

49. MARVIN, supra note 16 , at 40 . For a picture of the quartet, see id. at 22 .

Pinning down the company's exact evolution is a bit difficult. In his book, Marvin says that John B. West \& Company was established on October 21, 1876, and was incorporated as the West Publishing Company on October 22, 1882, with John becoming its president on November 1, 1882. See id. at 5 and 22. However, in West Publishing Co. v. Edward Thompson Co., 169 F. 833, 839 (C.C.E.D.N.Y. 1909), decree modified, 176 F. 833 (2d Cir. 1910), District Judge Chatfield says that John B. West \& Company was founded in 1874 , became a partnership known as the West Publishing Company in 1879, and then incorporated as the West Publishing Company on November 1, 1882. The company's web site provides still another timeline, saying that it was founded as the West Publishing Company in 1872 by John and Horatio and incorporated in 1882. See Thomson West, Historic Highlights, http://west. thomson.com/about/history/ (last visited Apr. 15, 2008). In all likelihood, however, a fourth version probably gets closest to the truth: 
1884 found himself surrounded by family both at work and at home. $\mathrm{He}$ and Lillian were living at 88 Park Place, while next door, at 90 Park Place, were his parents and his sister Louisa. 50

In 1887, the company moved into its own building at 52-54 West Third Street.51 As momentous as this development was, John topped it by announcing an audacious plan to catalog every case according to what he called the "American Digest Classification Scheme." 52 Like the case reporter, this marked a radical leap forward, for it allowed lawyers to quickly find decisions that had considered a particular issue. When the American Bar Association subsequently saw a prototype and enthusiastically embraced it, "West Publishing Company [became] the nation's acknowledged leader in indexing as well as reporting the case law of the country." 53 In time, West would increase the digest's utility by adding "key numbers," thereby giving every point of law its own permanent identifier. 54

\footnotetext{
A young St. Paul entrepreneur with experience as a traveling book salesman opened his first business in 1872, which he called John B. West, Publisher and Bookseller. West specialized in the sale of law treatises, legal forms, dictionaries, and office supplies. His most promising work, however, was in the trading of new and used court reports, a rare commodity at the time, given the notoriously sluggish official printing of state cases and verdicts. ...

In 1876, West convinced his older brother Horatio, an accountant, to join him in a new enterprise that would help to fill at least one identifiable and easily serviced void: that of recording Minnesota Supreme Court rulings. The business now became the John B. West Co. and the chief product, an eight-page weekly pamphlet of legal excerpts entitled The Syllabi....

The company's rapid growth caused the West brothers to seek outside capital to expand both its staff and manufacturing facilities. In the fall of 1882, Charles $\mathrm{W}$ Ames and Peyton Boyle officially became part of the business, now incorporated as a private concern.
}

Jay Pederson, West Publishing Co., in 7 International Directory of Company Histories 579-80 (Paula Kepos ed., 1993).

50. ST. PAUL CITY DiRECTORY FOR 1884-85, at 811 (1884).

51. MARVIN, supra note 16, at 130. For an overview of the giant plant's layout and functioning, see John WeSTHOLM WaLlace, A DesCRIPTION OF THE HOME ESTABLISHMENT OF THE National Reporter System, With Some account of the Business of the West PuBlishing CompanY, With Illustrations (1893).

52. MARVIN, supra note 16, at 68 . According to Marvin, this innovation came "[a]lmost out of the blue sky," id. at 69, although in fact a handful of other companies had been producing digests of various sorts for some time, with the two best known ones being Benjamin V. Abbott's United States Digest and John A. Mallory's Complete Digest. Id. at 69-70. By 1889 , both had been acquired by West. Id.

53. Id. at 74 (emphasis in original). As Marvin explains, John as usual had played the role of salesman:

The American Bar Association was due to meet for their annual convention in August 1897, just after the editorial work on Volume 1 was completed. West Publishing Company was desperately anxious to exhibit a completed volume at this convention, to gain expected approval and publicity, but the chances seemed remote that they could meet the deadline of the convention. . . Suffice to say, the volume was completed, taken to the convention by the then President, John B. West, and was the sensation of the meeting. The American Bar Association at its next annual meeting, 1898, formally endorsed the American Classification Plan as the model for modern digesting.

Id. at 73-74.

54. Id. at $79-81$. 
In 1888, Lucien Eaton, the editor of the American Law Review, sent a letter to the country's five largest legal publishers, asking them how law books should be written, printed, and sold.55 In addition to John, Eaton solicited Baker, Voorhis (New York), Bancroft-Whitney (San Francisco), Charles Soule (Boston), and Lawyers' Co-op (Rochester). 56

Baker, Voorhis and Bancroft-Whitney declined to participate, but the others responded, and their answers were published the following year. 57 While Soule's leadoff article was brief and gossipy, 58 John 59 and James E. Briggs, the president of Lawyers' Co-op, 60 used the occasion to debate what had become a hot issue, namely, whether they should publish all cases, leaving it to readers to decide each one's relative importance, or perform a sifting function and print only selected decisions:

The role of the publisher in all this was seen clearly by both sides. West's mission was "to supply the lawyer with the mechanical aids towards answering the question [What is the law?] in whatever connection it may arise." He felt his success should be a direct result of the manner in which he performed this service.

Briggs viewed his function very similarly-to render the decisions accessible. The difference lay in the fact that West considered them more accessible en masse, while Briggs considered no such collection of cases as facilitating in any way the knowledge of the present state of the law on any given question, but "complicates and embarrasses it" through sheer "quantity."

Who was responding to the more vital areas of the profession's wants and needs? West was giving the lawyers what they desired in their practice, indeed what they considered essential; Briggs wanted to give them what he thought they should want, what the law as a science or system needed. But of course, the law as a science does not purchase law books, the law in the person of the lawyer does; and West's insight perhaps can best be measured by his system's acceptance.61

After years of hard work, John now had a little time to enjoy the fruits of his labors. In 1893, he purchased a magnificent Victorian man-

55. Thomas J. Young, Jr., A Look at American Law Reporting in the 19th Century, 68 LAW LiBR. J. 294, 301-02 (1975).

56. Id. at 301 .

57. See A Symposium of Law Publishers, 23 AM. L. REv. 396 (1889) [hereinafter cited as 1889 Symposium]. As has been noted elsewhere, this is "[t]he earliest known American law review symposium issue[.]" Jean Stefancic, The Law Review Symposium Issue: Community of Meaning or Re-Inscription of Hierarchy?, 63 U. CoLo. L. REv. 651, 654 (1992).

To mark the symposium's centennial, Professor Thomas A. Woxland, assuming Eaton's role, wrote to 20 major legal publishers and asked them for contributions. The 14 responses he received were published simultaneously in a law review, see 11:3/4 LEGAL REF. SERVS. Q. 1 (1991), and a stand-alone book. See Symposium of Law Publishers (Thomas A. Woxland ed., 1991).

58. 1889 Symposium, supra note 57 , at $396-99$.

59. Id. at 400-07.

60. Id. at 407-14.

61. Young, supra note 55, at 302. In defending his approach (which critics labeled the "blanket" or "waste basket" system due to its lack of discernment), John managed to capture in one sentence his entire publishing philosophy: "No policy of insurance is so satisfactory to the insured as the blanket policy; and that is the sort of policy we issue for the lawyer, seeking insurance against the loss of his case through ignorance of the law as set forth in the decisions of the highest courts." 1889 Symposium, supra note 57, at 407. 
sion at 91 Crocus Place, which became his home for the next 20 years.62 In 1895, he was part of a delegation of dignitaries that saw off the ST. PAUL, the massive ocean liner built by the American Steamship Company at the William Cramp \& Sons Shipyard in Philadelphia.63 In 1897, he was made a 33rd degree Mason, 64 a rare honor given to members "who have served the [Order] or the community in extraordinary ways." 65 And in 1898, Louise, his first born, entered Smith College. 66

62. Lawrence A. Martin, Thursday Night Hikes: St. Albans/Lower Crocus Hill Architecture Notes, Part l, at http://www.angelfire.com/mn/thursdaynighthikes/stalb1_arch.html (last visited Apr. 15, 2008) [hereinafter cited as Thursday Night Hikes]. Designed by Charles E. Joy in the elaborate Queen Anne style, and built in 1886 for financiers Alvin and Horace Bushnell, the building now appears on the National Register of Historic Places as the Bushnell-West House, "a two story, 3877 square foot, five bedroom, three bathroom, one half-bathroom, frame house, with a two car tuck-under garage and a detached garage." Id. For a look at Joy's career, see Jefrrey A. Hess \& Paul Clifford Larson, St. Paul.'s ArChiTECTURE: A History 71-72 (2006). As these authors point out, Joy arrived in St. Paul in 1884, making the Bushnell-West House one of his first commissions.

63. At the time of her construction, the ST. PAUL, together with her sister, the ST. LOUIS, was the largest ship ever built in the United States. See WiLliam Henry FlayharT III, THE AMERICAN LiNE (1871-1902), at 170-71 (2000). The christening of the ST. LOUIS, attended by President and Mrs. Grover Cleveland, had proceeded without a hitch in November 1894. Id. at 178-81. But when it came time to float the ST. PAUL in March 1895, in a ceremony only a little less grand, the grease on her skids became so sticky due to a bout of unusually cold weather that the vessel refused to budge. As a result,

Two weeks of frantic activity ensued around the stranded hull of the St. Paul. Everyone was invited back for the second [successful] try on April 10, and many members of the official party from the city of St. Paul had enjoyed [the] extra two weeks in Philadelphia as the guests of the steamship line.

Id. at 186. As Flayhart notes, John was among those who stayed for the relaunching. $I d$. at 182-83, 364 .

64. Membership card of John Briggs West, showing that on October 22, 1897, the Supreme Council (Southern District) conferred on him the title of Inspector General Honorary (copy on file with the author). The card is both untitled and undated, and is the only record that still exists in the National Headquarters. E-mail from Joan K. Sansbury, Librarian/Curator, The Supreme Council-Ancient \& Accepted Scottish Rite, Southern Jurisdiction, U.S.A., to the author, Dec. 17, 2007, 1:51 p.m. (copy on file with the author).

From another source, however, we know that John was a member of the Carmel Lodge of Perfection, No. 1, A. \& A. S. R., which met on the third Monday of each month at the Masonic Hall on the corner of Third and Wabasha Streets. See ST. PAul CiTY DiRECTORY $1890-91$, at 100 (1890) (listing John as the chapter's Senior Warden).

65. Christopher Hodapp, Freemasons for Dummies 301 (2005). See also S. Brent MORRIS, THE COMPLETE IDIOT's GUIDE TO FREEMASONRY 121 (2006) ("Masons are nominated to receive the $33^{\circ}$ on the basis of service to the fraternity or to humanity. A total of about 1.5 percent of all Scottish Rite Masons have received the $33^{\circ}$, and in America this represents about 0.5 percent or one out of every 200 Masons.").

66. After studying English and drama, Louise earned a B.L in 1902. See Catalog of Officers, Graduates and Nongraduates of Smith College, 1875-1910, at 131 (1911). Shortly after graduating, she revealed that as a freshman she had been amazed that no one cared who her father was: "A college is practically a world in itself, and at first it is rather a shock to a girl to find that her position at home counts for so little in it in one way or another; that she stands on her own feet and for herself." Louise Bronson West, Distinction Without A Difference, 10 SMith C. MoNTHLy 48, 48 (Oct. 1902). 


\section{IV}

\section{JOHN AFTER WEST}

In 1899, John suddenly left West. A short time later, the American Law Review ran a brief item explaining what had happened:

Possibly it may not be generally known that Mr. John B. West, the founder of the West Publishing Company, has retired from that corporation. It is said that disagreements arose, under the stress of which one of his associates purchased his shares for a round sum of a quarter of a million dollars. ${ }^{67}$

Whether John was pushed out or walked out is not known. In either event, he immediately began making plans to reenter publishing, and within three weeks had opened the Keefe-Davidson Law Book Company. 68 Its

67. Consolidation of the American and the General Digest, 34 AM. L. REv. 243, 243 (1900). Another source states, without elaboration, that John left West "after a major rupture between family members." Virginia L. Martin, The View From the 17th Floor: Oppenheimer Wolff \& Donnelly and Its 111-Year History, 32 RamsEy CounTy Hist. 4, 4 (Fall 1997), available at http://www.rchs.com/oppenheimer/oppenheimer.htm (last visited Apr. 15, 2008) [hereinafter cited as View From the 17th Floor]. Although it is unclear who purchased John's shares, what evidence exists points strongly to Charles Ames.

According to the inflation calculator at www.westegg.com, $\$ 250,000$ in 1899 is the equivalent of $\$ 6.15$ million today. To this sum one has to add the fact that just a short time earlier, the United States Supreme Court had abolished the federal income tax (due to constitutional objections arising from its lack of apportionment). See Pollock v. Farmers' Loan \& Trust Co., 157 U.S. 429, aff $d$ on reargument, 158 U.S. 601 (1895). Thus, John's payday was indeed a hefty one.

Back at West, John's departure meant Horatio was in charge, but within just a few months poor health led him to turn the company's day-to-day affairs over to Ames. MARVIN, supra note 16, at 95-96. While Horatio remained president until August 1908, id at 4, the days of a West running West effectively were over.

68. Compare MARvin, supra note 16, at 5 (listing John's last day at West as August 21, 1899) with Articles of Incorporation of Keefe-Davidson Law Book Company, Sept. 5, 1899 at $\mathbb{2} 2$ ("The time of commencement of said corporation shall be the 12th day of September, 1899") (copy on file with the author) [hereinafter cited as 1899 AOI]. Any doubt that John intended to go head-to-head with West was dispelled right at the outset:

The name of this corporation shall be "Keefe-Davidson Law Book Company;" the business of said corporation shall consist of the publishing, buying, and selling of law books and law publications of every kind whatsoever, and the conducting of a general business for the purpose of purchasing and selling law books and law publications. The principal place of business of said corporation shall be in the City of St. Paul, Ramsey County, Minnesota.

1899 AOI, supra, at 11 .

In 1908, the name of the company was changed to the Keefe-Davidson Building Company and paragraph 1 was rewritten as follows:

The name of this corporation shall be "Keefe-Davidson Building Company."

The business of said corporation shall consist of the publishing, buying, and selling of law books and like publications of every kind whatsoever, and the conducting of a general business for the purpose of purchasing and selling law books and law publications; also the business of buying, owning, improving, selling and dealing in lands, tenements and hereditaments, including the right to use and enjoy the same, and to lease, let, mortgage or otherwise dispose of or charge or encumber said lands, tenements and hereditaments or any right or interest therein at pleasure, and in such manner and on such terms as may be determined by order of the board of directors or established by the by-laws, and, for that purpose to make and deliver, and in like manner accept and receive, all necessary and proper deeds, conveyances, mortgages, promissory notes, bonds, leases and other contracts and writings obligatory, and to have and exercise all necessary rights, franchises, muniments, estate, powers and privileges necessary to that end. 
president was William A. Keefe and its secretary-treasurer was Earnest $\mathrm{H}$. Davidson, 69 both former West employees. 70 But they were mere figureheads, for John clearly was in charge.71

In addition to starting a new business, John also was busy building a new house. Designed by Clarence H. Johnston, the city's leading residential architect, 72 the handsome structure going up at 653 Grand Avenue was a two-story, 3,500 square foot Colonial Revival. 73 When it was finished, John moved his parents and his sister Louisa into it. 74

During the next few years, a number of other changes took place in John's life. In 1902, his oldest son, John Jr., left for Harvard, followed the next year by his second son, Donald. 75 In 1903, John helped organize the

The principal place of business of said corporation shall be in the city of St. Paul, Ramsey County, Minnesota.

Amendment to Articles of Incorporation, Jan. 3, 1908 (copy on file with the author).

69. See 1899 AOI, supra note 68, at II 6 ("The President of said corporation shall be William A. Keefe and the Secretary and Treasurer thereof shall be Earnest H. Davidson, and said persons shall hold office until their successors are duly elected and qualified as herein provided.").

70. MARvin, supra note 16 , at $92-93$. Although research reveals little about Keefe, a profile of Davidson reports that he was

[b]om May 20, 1873 in St Paul, son of Col James $\mathrm{H}$ and Abbey A Davidson. Was educated in the public and high schools of St Paul and started to work 1892 in Bayfield Wis as clk for American Express Company. Removed to St Paul and entered his father's office; later was head bookkeeper in Union Bank; with West Publishing Co as accountant, salesman and $\mathrm{sec}$ to the pres 1892-99, resigning to inaugurate the Keefe-Davidson Law Book Co for which he was sec and treas for 4 years until he entered the life insurance business [1903]; special representative of the Northwestern Mutual Life Ins Co of Milwaukee to date.

LITTLE SKETCHES, supra note 4, at 101-02

71. MARVIN, supra note 16, at 93 ("Messrs. Davidson and Keefe withdrew [from West] in 1899 to become associated with John West in his new publishing venture.") (emphasis added). While John never assumed the title of president, he did eventually become the company's vice president. See, e.g., St. PAUL CITY DIRECTORY FOR 1911, at 936, 1748 (1911).

72. For an examination of Johnston's career, see PAUL Clifford LARSON, MinNesota ARChITECT: The Life AND Work OF ClaRENCE H. Johnston (1996).

73. Thursday Night Hikes, supra note 62. See also LARSON, supra note 72, at 172 (indicating that the house was one of three that Johnston designed in 1899 and cost $\$ 4,000$ to build).

74. Thursday Night Hikes, supra note 62. Now known as the "John B. West House" and listed on the National Register of Historic Places, id., it was put up for sale by its current owner, Dr. Sarah C. Chambers, in 2007 for $\$ 650,000$. See Edina Realty, 653 Grand Avenue-MLS \# 3473892, http:/www.edinarealty.com/Listing/ListingDetail.aspx?Listing= 27040272 (last visited Apr. 15, 2008). In the meantime, she continues to use it for her chiropractic practice. See http://www.crocushillhealthcenter.com (last visited Apr. 15, 2008).

75. John Jr. graduated in 1906 with an S.B., while Donald was awarded an A.B. in 1907. See HaRVARd UNIVERSITY DiRectory 716 (1910).

So that they would have a comfortable place to live while they pursued their studies, John took over what had been the house of lawyer-turned-philosopher John Fiske, who had passed away unexpectedly in July 1901. The large dwelling soon became a home-away-from-home for John, as the family's entry in the local social register makes clear:

\section{BERKELEY STREET, Cambridge}

22 Mr. \& Mrs. John B.West

At home Wednesdays

Miss Louise B. West

John B. West, Jr.

Donald West 
American National Bank and became one of its first directors. ${ }^{76}$ In 1904, his father died of "senility," 77 while in 1905 his mother passed away from "old age."78

In 1908, the American Association of Law Libraries held its third annual meeting at Lake Minnetonka, Minnesota. 79 John was one of the speakers, and his talk was entitled, "A Possible Solution of the Problem of the Multiplicity of Law Reports." 80 In 1909, the speech was reprinted in the fledgling Law Library Journal.81

BLUE BOOK OF CAMBRIDGE 1904, at 41 (1903). For a further description of the house and pictures of its exterior and interior, see II JoHn SPENCER CLARK, The LifE AND LeTters of JohN FISKE 79-82, 94a (1917).

76. See St. PAUl. CITY DiRECTORY FOR 1903, at 175 (1903). As has been explained elsewhere, the bank's roots can be traced to the Panic of 1893 :

While serving as city treasurer, Otto Bremer became a charter member of the board of directors for the American National Bank. The bank was formed in 1903 through the merging of two St. Paul banks. Bremer held 50 of the 2,000 shares of capital stock. The charter members of the board of directors, well aware of potential pitfalls, operated a conservative banking business, unlike the days of wild growth [in the late 1880s and early 1890s] when banks and customers were extended beyond their means. . .

Otto Bremer increased his holdings in the bank, becoming a major shareholder by 1916 . .. In 1921, Benjamin Baer, the bank's second president and an original board member, died. Otto Bremer was named chairman. He also bought much of Baer's stock and by 1924 gained controlling interest in the bank. ... After Bremer's death in 1951, the banking chain entered an extended period of consolidation. The ... descendants of Adolph Bremer [Otto's brother] held stock in American National until it was sold to Milwaukee-based Firstar Corp. in 1996 [now U.S. Bancorp].

Bremer Financial Corp., http://www.referenceforbusiness.com/history2/5/Bremer-FinancialCorp.html (last visited Apr. 15, 2008).

77. See supra note 5.

78. See supra note 7.

79. Franklin O. Poole, American Association of Law Libraries, 33 Libr. J. 276 (1908).

80. Id. at 276 . John had sketched out some of the ideas contained in this talk in an earlier piece:

Mr. John B. West, the well-known publisher of St. Paul, in a recent issue of Current Law (Vol. vi, No. 4) publishes a brief monograph entitled "Universal Citations for All Opinions." He calls attention to the necessary multiplication of citations caused by the different unofficial publications of reports ... [and] contends that reports of decisions are simply official documents which should be filed in numerical order and cited with reference to their numbers. Under this system no matter how many decisions or systems of reporting be adopted each case can be readily found and cited by reference to this official number, entirely regardless of the volume and page of the particular publication.

Citation of Opinions, 19 GrEen BAG 361, 361 (1907). Of course, when West ended up comering the reporter market, John's idea was forgotten. In 1994, however, Wisconsin resurrected it-without giving John credit—and implemented it in 2000 over West's strenuous objection, becoming the first of what remains a small number of states to do so. For a further discussion of so-called "neutral" or "universal" citation systems, see, e.g., Ian Gallacher, Cite Unseen. How Neutral Citation and America's Law Schools Can Cure Our Strange Devotion to Bibliographical Orthodoxy and the Constriction of Open and Equal Access to the Law, 70 Alb. L. Rev. 491 (2007); Peter W. Martin, Neutral Citation, Court Web Sites, and Access to Authoritative Case Law, 99 LAw LiBR. J. 329 (2007); James H. Wyman, Comment, Freeing the Law: Case Reporter Copyright and the Universal Citation System, 24 FLA. ST. U. L. REV. 217 (1996).

81. John B. West, Multiplicity of Reports, 2 LAW LIBR. J. 4 (1909) [hereinafter cited as Multiplicity]. 
The article is a tough but fascinating read. 82 In it, John called for the elimination of unofficial case reporters, the bread-and-butter of his former firm:

So far as the problem of the multiplicity of reports is caused by duplication of decisions in different publications, the solution seems to lie in making the publication of the official reports as prompt as the unofficial. That done, the unofficial publications will have fulfilled their chief mission. From the standpoint of a lawbook man this does not seem difficult. 83

He likewise derided the West digest system, claiming it had outlived its usefulness and arguing he had come up with a better method:

Perhaps nothing has done more to prevent the permanency of digests than the false theory that cases and propositions dealing with changing conditions may be made to fit a rigid classification instead of permitting the classification to change gradually with the growth of the case law. The classification of today will be as inadequate in the future as the classification of the past is at this time...

The digester bound to a fixed classification soon finds himself sorely pressed to make certain cases "fit the classification." I remember three excellent digesters who spent an entire day in disagreeing as to whether seal fishery cases should be classified under the topic "Fish" or that of "Game" in the Digest Scheme. It is the old story of the camel's head in the tent. What seems at first a plausible pretext for forcing some novel case or new principle into a topic or subdivision to which it does not naturally belong, leads to hopeless confusion. The only remedy has been recompilation.

Given properly constructed original digest paragraphs, compiled by the man who wrote them, and an elastic scheme, supplements thereof can be readily produced, each of which will be complete within itself as to the new cases. I have myself published such digests. If any of you will call at our establishment at St. Paul, I will be pleased to show you a set of reports canceled out line by line, showing how each case was written up topic by topic, examined by sometimes as many as five editors, proceeding from the last volume back to the first, and following up every citation made by the court. When you have examined this you will not need to be told that lawyers and judges alike say that the digest so produced is the best they ever saw. In that state there is now little multiplicity of digests. 84

Taking swipes at his former colleagues, however, was not the only thing on John's mind. For two years, he had been in a royalty dispute with William L. Clark, an author he had brought over from West. 85 Now, the matter was going to trial, 86 forcing John to spend considerable time huddling with his lawyers. In the end, Clark prevailed. 87

82. Hence the awkward summary of it by the Law Library Journal's editors in 1982. See supra note 3 and accompanying text.

83. Multiplicity, supra note 81 , at 5. For the importance of case reporters to West's bottom line, see MARviN, supra note 16, at 57 ("The Reporters, collectively known as the National Reporter System, from the earliest days have been the source of the company's growth and prosperity.").

84. Multiplicity, supra note 81 , at 7 .

85. See infra note 87.

86. See Drank and Lost His Pay; Legal Writer Broke Abstinence Contract, But Sues to Collect, N.Y. Times, Apr. 17, 1909, at 6.

87. See Clark v. West, 110 N.Y.S. 110 (App. Div.), rev'd, 86 N.E. 1 (N.Y. 1908), later proceedings at 122 N.Y.S. 380 (App. Div. 1910), aff d mem., 95 N.E. 1125 (N.Y.), reargument denied, 95 N.E. 1126 (N.Y. 1911). As has been noted elsewhere, the litigation has become a law school staple: 
Losing the case was symptomatic of the many hardships John faced daily at Keefe-Davidson. In an otherwise effusive review of a legal prose anthology, for example, The New York Times lamented the editor's choice of publisher:

Mr. Van Vechten Veeder has done so good and thorough a piece of work in compiling and editing a book that he calls "Legal Masterpieces" that one regrets that he should not have taken more pains to render it accessible. It is published by the Keefe-Davidson Company in St. Paul, Minn., a firm which may reasonably be supposed to be out of the beaten track of publishing in this country, and not to have the best means of bringing its wares to the attention of those whom they might concern. 88

The firm's difficulty in attracting notice becomes painfully obvious when one examines its treatment in a local guidebook. While West received its own, 300-word entry, Keefe-Davidson was allotted one sentence; to add insult to injury, it appeared at the end of the West write-up. 89

Matters became particularly desperate for the company in 1909, and that fall John was forced to pull Bronson, his youngest son, out of school. Bronson had been a freshman at Harvard during the previous term, and his inability to continue was a profound blow to both parent and child:

When I was supposed to return [after] my freshman year in Harvard, my father suffered severe financial reverses. He was not a college man, himself, and he felt very badly about my not completing my college education. I had my room engaged for my sophomore year, and I intended to specialize in English as I had

On this date [November 10th] in 1908, the famous Case of the Drunken Law Professor enters the pantheon of contracts classics, as the New York Court of Appeals decides the case of Clark $v$. West, 193 N.Y. 349; 86 N.E. 1 (1908).

William Lawrence Clark, Jr. (1863-1918), was a prolific legal writer. In 1894, West published the first edition of his Handbook of the Law of Contracts, a book still going strong over a half-century later when the 4 th edition was relied on by the Virginia Supreme Court in Lucy v. Zehmer (1954). In 1897, he wrote the first edition of his popular Handbook of the Law of Private Corporations, which was published by West. Two years later he was hired to teach at the law school at Washington \& Lee. His career hit a major speed bump a few weeks into his term at $W \& L$, when he was fired because he was found to be "addicted to drinking" to such an extent that his carouses had made the New York papers.

Publisher John B. West wanted a new edition of Clark on Corporations. Clark agreed to do one, and the parties signed a contract [in February 1900] under which Clark was to be paid $\$ 2$ a page if he drank alcoholic beverages and $\$ 6$ a page if he totally abstained. Clark, as might be supposed, did not stay long on the wagon. The book was published in 1907 but West refused to pay him more than $\$ 2$ a page. Clark sued and won, in an opinion . . . that is still used to mystify students about what exactly a "waiver" is.

Franklin G. Snyder, Today in History: Clark v. West, http://lawprofessors.typepad.com/ contractsprof_blog/today_in_history/index.html (Nov. 10, 2005) (last visited Apr. 15, 2008).

88. "Legal Masterpieces," N.Y. Times, Aug. 22, 1903, at BR6 (reviewing LEGAL MASTERPIECES: SPECIMENS OF ARGUMENTATION AND EXPOSITION BY EMINENT LAWYERS (Van Vechten Veeder ed., 1903)). When a modern reviewer stumbled across the text, he had a similar reaction:

Some years ago, in an out-of-the-way bookshop, I picked up a book entitled Legal Masterpieces, Specimens of Argumentation and Exposition by Eminent Lawyers. It bears a publication date of 1903 and carries the name of Keefe-Davidson Company as the publisher. Van Vechten Veeder is listed as the editor. I have never heard of either the publisher or the editor.

Jacob A. Stein, Old Time Oratory, 12 LrT. 59, 59 (Fall 1985).

89. See 1 Henry A. Castle, History of St. Paul and Vicinity 337 (1912). 
received an honor $\mathrm{A}$ in English. However, I had to make a decision. My father needed my assistance, so I gave up college and went to work. Both my brothers had graduated from Harvard and had received degrees. Some way or other, I felt that was the one thing I was being deprived of, a degree. Maybe, I exaggerated the importance of it, but it seemed, at the time, that the lack of a degree was going to handicap me all through my life. 90

During the next two years, the firm's position continued to deteriorate, 91 and in 1912 it finally was forced to shut down ${ }^{92}$ (although its name later was briefly revived 93 ).

90. Harvard College Class of 1912: Twenty-FifTh AnNiversary Report 763-64 (1937).

As things turned out, Bronson was able to overcome his lack of a degree. After returning to St. Paul (where he spent the remainder of his life) and joining John at Keefe-Davidson, he married Marjorie C. Bemis (1912) and had a son, Bronson Jr. (1913), who succumbed to infantile atrophy when he was three months old. In 1915, Bronson started his own legal printing business, see infra note 93 , but in 1919 he switched professions and became an advertising executive. He died in 1950, survived by his daughters Ann (b. 1914) and Marjorie (nicknamed Peggy) (1921-2007). Id. at 763; Harvard Class of 1912: FifTIETH ANNIVERSARY RePORT 582 (1962); Bronson West Dies, supra note 48; Thursday Night Hikes, supra note 62; Bronson West Death Certificate, supra note 48; Telephone Interview with Dr. Donald $M$. West in Sunnyvale, Cal. (May 5, 2008).

In his later years, Bronson also ran a legal research service called "Cases in Point." For $\$ 10$, lawyers could submit a statement of facts and receive in exchange a list of relevant authorities. Ads for the service included a disclaimer advising readers that "Bronson West has no connection with the West Publishing Company. His father, however, was John B. West, founder of that company and the National Reporter and American Digest Systems."

91. As the end grew near, a bit of gallows humor emerged:

The Keefe-Davidson Company of St. Paul, Minn., inform us that they recently devised a rubber stamp for use in collecting bills, bearing the following motto: "Of all the words that are spoke or writ, the saddest of all are, "please remit."'

A Nevada lawyer, who evidently was possessed of [a] considerable sense of humor, wrote to the firm annotating the rubber stamp on his bill with the following inscription: "Or all the words that are sung or spoke, the saddest of all are 'I am broke."

The rubber stamp was banished forthwith.

A Dun Outdone, 23 GREen BAg 552, 552 (1911).

92. See Bigelow v. Barnes, 140 N.W. 1032, 1033 (Minn. 1913) ("The Keefe-Davidson Company is a corporation, and was heretofore engaged in the publication and sale of law books. ... The corporation ceased all business operations in January, 1912, and plaintiffs were then duly appointed and commissioned by the district court of Ramsey county receivers to wind up its affairs.").

The firm's receivers were Herbert H. Bigelow (co-founder of Brown \& Bigelow, a calendar manufacturer), Eli S. Warner (the general manager of McGill-Warmer, a printing company), and William $\mathrm{H}$. Oppenheimer (who at the time had a solo law practice). For their biographies, see, e.g., Rod Bigelow, Herbert Huse Bigelow, http://bigelowsociety.com/rod9/her 92371.htm (last visited Apr. 15, 2008); II John Clyde Oswald, Printing IN the AMERICAS 444 (1937) (Warner); View From the 17th Floor, supra note 67 (Oppenheimer).

A letter written by the trio to one of Keefe-Davidson's former customers has survived. See http://www.bchm.org/Holdings/Collections/CollectionOnline/exhibit3/e33609a.htm (last visited Apr. 15, 2008) (copy on file with the author). As it makes clear, they had just as hard a time as John when it came to collecting from lawyers. Addressed to W.T. Williams of Angleton, Texas, the letter is dated November 27, 1912, and reads as follows:

\section{Dear Sir:}

Don't you think that a settlement on a basis of 50\% is very fair? We do, therefore, shall draw at sight on Dec. 4th through the Angleton State Bank for \$14.75. This amount when paid will be accepted in full of your $\$ 29.50$ account. 
Distraught over the company's failure, John Jr. suffered a nervous breakdown and hung himself at St. Peter State Hospital, a mental institution he had been admitted to for treatment. 94 The circumstances surrounding his death were later recounted as follows:

After graduating [from Harvard in 1906], he entered the employ of a law-book publishing house in St. Paul, and soon became its secretary. Of a highly sensitive nature with a delicate sense of right and honor, the strain of a long fight against a "reorganization committee" for the rights of stockholders, which the committee was prone to disregard, broke his health completely. 95

Crestfallen by these events, in 1913 John moved to the wealthy Los Angeles suburb of Pasadena. 96 In choosing this location, John was following in the footsteps of other prominent Midwesterners, 97 as well as his brother Horatio, who was living in neighboring Altadena.98

Please make your arrangements accordingly, and oblige,

Yours truly,

Herbert H. Bigelow, Eli S. Warner and Wm. H. Oppenheimer Receivers for the Keefe-Davidson Co.

93. In March 1915, Bronson West helped start a Minneapolis printer called The Legal Publishing Company. See Articles of Incorporation of The Legal Publishing Company, Mar. 15,1915 (copy on file with the author). Three months later, it changed its name to the KeefeDavidson Company (presumably to take advantage of whatever good will still existed). See Certificate of Amendment of Articles of Incorporation of The Legal Publishing Company, June 14, 1915 (copy on file with the author). Subsequently, it transferred its headquarters from Minneapolis to St. Paul. See Certificate of Amendment of Articles of Incorporation of Keefe-Davidson Company, Apr. 4, 1917 (copy on file with the author). Although records are sketchy, it appears the firm lasted until about 1920. See ERWIN C. SURRENCY, A History of AMERICAN LAW PUBLISHING 239 (1990).

94. See John B. West, Jr. Death Certificate, supra note 45.

Founded in 1866 as the Minnesota Asylum for the Insane and located 70 miles south of St. Paul, St. Peter had a reputation for providing humane therapeutic services and placing an emphasis on rehabilitation. See Mark Weinberger, Minnesota: A Guide to UniQue Places 86 (8th ed. 2007). For a picture of St. Peter as it looked in John Jr.'s day, see St. Peter Regional State Hospital, http://www.rootsweb.com/ asylums/stpeter_mn/index.html (last visited Apr. $15,2008)$.

95. Secretary's Third RePort-Harvard College Class of 1906, at 425 (1916).

Shortly after joining Keefe-Davidson, John Jr. had enrolled in the night law school at the University of Minnesota. In 1909, however, he was forced to drop out when, as explained supra text accompanying note 90 , John found himself in financial difficulty. See E-mail from Karen Klinkenberg, Library Assistant, University of Minnesota Archives, to the author, Mar. $10,2008,12: 32$ p.m. (copy on file with the author) (confirming that John Jr. was a student at the school from 1906 to 1909 but did not graduate).

96. MARVIN, supra note 16 , at 25 . How John was able to afford this move (and his subsequent retirement) is an interesting question, for which no answer has been found.

97. See Colleen Dunn Bates, Hometown Pasadena: The Insider's Guide 33 (2006) ("From the 1890 s through the $1920 \mathrm{~s}$, Midwestern business magnates built grand winter homes in the greater Pasadena area, including map publisher Andrew McNally; razor monarch King Gillette; plumbing heiress Kate Crane Gartz; patent medicine millionaire Colonel G. G. Green; newspaperman William Scripps; the king and queen of clean, David and Mary Gamble; artist Grace Nicholson; chewing-gum tycoon William Wrigley; Anna Bissell McKay, daughter of the emperor of vacuum cleaners; Lucretia Garfield, widow of President Garfield; Henry and Arabella Huntington; and utopian and sometimes Socialist muckraker Upton Sinclair and his wife, Mary."). Today, the influence of these early millionaires continues to be felt: 
Once in California, John settled into a quiet life, the high point of which was the 1920 society wedding of his son Donald.99 In February 1922, John's health began to fail, and on the evening of March 14, 1922, he died at his home from heart disease. 100 Two days later, a funeral was

Nestled in the San Gabriel Valley just 10 miles northeast of Los Angeles, Pasadena harbors a distinct, if at times chauvinistic sense of individual self. Its old-money past continues to flourish in the form of grand mansions and a vast array of museums and gardens, many underwritten by prominent local families. And newer money has helped transform Old Pasadena, in decline for many years, into an energetic shopping and dining destination, with quirky shops and new restaurants. But it is the expansive outdoors, mountain views and fine climate (except in August, when you could fry a hot dog at the Rose Bowl) that still make Pasadena, the famed City of Roses, a shining jewel of Southern California and an enduring object of jealousy.

Jennifer Steinhauer, 36 Hours in Pasadena, Calif., N.Y. Times, Mar. 16, 2008, at 12 (Travel).

98. Although it is not entirely clear, Horatio probably moved from St. Paul to Altadena (also known as "Upper Pasadena") sometime in 1900, or shortly after he ceded day-to-day control of the company to Ames. See supra note 67. Support for this date comes from the fact that Horatio's daughter Alice was married in Altadena in April 1901. See GuY S. RIX, History and GENEAlOGY OF THE EASTMAN FAMILY of AMERICA 892 (1901). For at least a little while, however, Horatio considered both cities his home. Thus, when he applied for a passport in 1903 for a trip to Europe, he listed his permanent residence as "Altadena Calif and St Paul." See United States of America, Form for Native Citizen, No. 77440, Aug. 15, 1903 (copy on file with the author).

The fact that the two men ended up spending their retirements in such close physical proximity (John's house at 855 El Campo Drive in Pasadena was less than 10 miles from Horatio's house at 230 East Calaveras Street in Altadena) is obviously noteworthy, for it suggests that they either got over their 1899 fight, see supra note 67, or John's departure from West was not caused by Horatio.

99. For those unable to wangle an invitation, the press provided a preview:

An interesting event scheduled for the evening of Tuesday, June 8 , is the marriage of Miss Hildreth Dana Markham, daughter of former Gov. and Mrs. H. H. Markham of Pasadena, to Mr. Donald West of Sunny Slope. The ceremony is to be in the Neighborhood Church at Pasadena, and will be performed by Dr. Hitchcock in the presence of relatives and intimate friends. A small reception will follow. After a motor trip the couple will reside at Mr. West's handsome home in Sunny Slope. He is the son of Mr. and Mrs. J. D. [sic] West of St. Paul, Minn.

Virginia Woods, Society: To Wed in Pasadena, L.A. TIMes, May 26, 1920, § II, at 3.

The couple went on to have a long marriage, which ended in November 1974 when Donald passed away. See supra note 46 . Their union produced two children, named Mary (b. 1922) and Donald (b. 1925), see HARVARD Class OF 1907: TWENTY-FIFTH ANNIVERSARY REPORT 722 (1932), and together with Bronson's three children, see supra note 90, these were the only grandchildren John had due to the fact that John Jr., Katherine, and Louise never married. See supra notes 44,45 , and 47.

In 1989, Mary's daughter Susan (1956-97), a 1987 graduate of the University of San Francisco School of Law, was admitted to the California Bar. See http://members.calbar.ca. gov/search/member_search.aspx?ms=susan+adams+baker (showing that Susan Adams Baker of Berkeley was admitted in June 1989 and assigned California Bar Number 139865); Telephone Interview with G. Burnham Atterbury, Assistant Dean-Law School Development, University of San Francisco in San Francisco (May 6, 2008). To date, she is the only one of John's direct descendants to become a lawyer. Telephone Interview with Mrs. Mary D. Baker in Berkeley, Cal. (May 5, 2008).

100. West Funeral Arranged, St. PAUl Pioneer Press, Mar. 16, 1922, at 2; California State Board of Health-Bureau of Vital Statistics, Certificate of Death for John West, Mar. 15,1922 (copy on file with the author).

Heart disease affected many members of John's family, including his brother Horatio, his sisters Lillie and Louisa, his daughters Katherine and Louise, and his sons Bronson and Donald. See supra notes 10-12, 44, and 46-48. 
held at the Ives \& Warren chapel in Pasadena,101 presided over by Dr. John Crosser, the pastor of the Neighborhood Church. 102 Following the service, John's body was taken to the Mountain View Cemetery in Altadena and cremated. 103 In June 1936, his ashes were sent back to Minnesota104 and interred in the West family plot at St. Paul's Oakland Cemetery. 105

\section{$\mathbf{V}$ \\ CONCLUSION}

The St. Paul Dispatch put the news of John's passing on its front page, calling him "one of the best known publishers in America" and lauding him as the originator of "the National Reporter system, the Cyclopedic Digest, Current Law and other systems widely used in the printing of law books." 106 Yet today, nearly 90 years after his death, there is not even one biography of the man who transformed the way American law is collected, organized, and disseminated.107 The West Publishing Company's "official

101. John B. West, Pasadena Star News, Mar. 15, 1922, at 2.

102. Id.

103. John West Death Certificate, supra note 100.

104. E-mail from Alice C. Volkert, Principal, Volkert Services, to the author, Mar. 26, 2008, 9:17 p.m. (copy on file with the author).

105. John's ashes are in Lot 16 , Block 9, Grave 6, where they are marked by a large, white, stone stele. Due to the passage of time, the monument is virtually unreadable, but a close examination reveals that John's name, date of birth, and date of death are chiseled into the east face. Other graves in the plot hold the remains of his sister Fannie (Grave 1), his father William (Grave 2), his mother Louisa (Grave 3), his son John Jr. (Grave 4), his grandson Bronson Jr. (Grave 5), and his son Bronson (Grave 7). For a further look at the cemetery, which was founded in 1853 and from the beginning was both non-sectarian and the final stop for many of the city's elite, see Robert Orr Baker, Oakland Cemetery: 'A Safe and Permanent Resting Place,' 16 RaMSEY COUNTY HIST. 3 (Fall 1980); Oakland Cemetery, hitp://horticulture. cfans.umn.edu/gardens/gardens-metro/Oakland-Cemetery.htm (last visited Apr. 15, 2008); Oakland Cemetery, http://www.parkbooks.com/MnGenWeb/oakland.html (last visited Apr. $15,2008)$.

The remaining members of John's immediate family are buried in California. His wife Lillian and his daughters Katherine and Louise are in Lot 305, Block U, Graves 1 and 2 (Lillian and Louise share Grave 2) in San Gabriel Cemetery (www.sangabrielcemetery.com), a five minute drive from Pasadena, while son Donald is in the Markham family plot (Lot 190 ) in the Mountain View Cemetery (www.mtn-view.com) in Altadena.

106. J. B. West, Veteran Law Publisher, Dies; Founder of Noted Firm Succumbs to Heart Disease in Pasadena Home, St. PAul DiSPatch, MAR. 15, 1922, at 1.

107. On at least one occasion, however, John came close to getting a biography. In the 1980s, Professor Robert C. Berring, Jr., considered the idea but then "I began to write about the impact of West and how ... the West Company changed the way that we think about the law. I published a string of articles from that beginning but the biography idea drifted off." E-mail from Robert C. Berring, Jr., Walter Perry Johnson Professor of Law, University of California-Berkeley, to the author, Feb. 25, 2008, 4:30 p.m. (copy on file with the author).

In one of his articles, Berring, while calling John "one of my favorite historical characters," observed that "most people who knew [him] thought of him as a very strange person." See Robert Berring, Full Text Legal Research: Implications for the Future, 14 CALL NEwSL. 186,186 (1989). Later in the same piece, Berring neatly summarized John's contributions: 
history" skims over his life, explaining that few records exist. 108 The leading reference work on legal publishing is likewise short on details, 109 as is the esteemed Oxford Companion to American Law.110 Searching on WESTLAW produces only a handful of scattered references. 111

It is rather stunning that so pivotal a figure wallows in such obscurity. Of course, John's falling out with West, and his subsequent decision to start a competitor, has given the company ample reason to downplay his contributions. 112 The disappearance of the Keefe-Davidson firm means we have almost no records from what, arguably, was the most important part of his life. And his long and quiet retirement in Pasadena, so far removed from St. Paul, caused him to slip out of sight even before he was dead.

Other factors also have worked against John: the commonness of his name113; the understandable tendency to mistake it for a geographical indicator114; the fact that as a family business, the payroll once had lots of

[John B. West] had two great ideas, first, the comprehensive reporting of decisions and the second, arranging them in a comprehensive digest. In considering the concept, it was amazing to attempt to set up a subject system which would index and arrange every possible legal point which could ever be decided. Under the West system there is no legal issue that has been decided in American courts that does not have a location somewhere in that West digest system. That is the beauty of the system. There is a topic and subtopic for everything. Of course that has had an enormous impact upon American law as well. That arrangement ... still reflects the way most American decisions are arranged. This also tracks many of the ways we break up the law in the courses that we teach in our law schools.

Id. at 186-87.

108. See MARVIN, supra note 16 , at 23-24.

109. See SurREnCY, supra note 93, at 237-41.

110. See Oxford Companion to American Law 680 (Kermit L. Hall ed., 2002).

111. Most of these articles, in turn, cite to either Thomas A. Woxland \& Patti J. Ogden, Landmarks in American Legal Publishing: An Exhibit Catalog 38-40 (1990), or Thomas A. Woxland, "Forever Associated with the Practice of Law": The Early Years of the West Publishing Company," 5 Legal Ref. Servs. Q. 115 (Spring 1985).

112. With her tongue firmly planted in her cheek, however, a West official has stated that "it[']s been tempting to add him [John B. West] to FaceBook for fun." E-mail from Gretchen DeSutter, Senior Communications Specialist, Thomson West, to the author, Feb. 29, 2008, 3:02 p.m. (copy on file with the author).

113. Although by no means scientific, the web site HowManyOfMe.com reports there presently are 3,987 Americans with the name "John West." Among current individuals with the name "John B. West," at least two are lawyers. See http://www.hullfirm.com/attorneys/ jwest.html (last visited Apr. 15, 2008) (tax lawyer in Augusta, Georgia) and http://www. ogilvyrenault.com/en/OurPeople/ProfessionalBio.aspx id $=841$ (last visited Apr. 15, 2008) (labor lawyer in Toronto).

114. See, e.g., Newton W. Lamson, For Lawyers, West Isn't a Direction-lt's a Way of Life, 4 JuRIS Doctor 28 (Feb. 1974). In the 1870s, of course, Minnesota was in the West. See, e.g., Legal News and Notes, 3 CENT. L.J. 746, 746 (1876) ("We acknowledge the receipt of another Western legal publication, The Syllabi, published weekly by John B. West \& Co., St. Paul, Minnesota. It is local in its scope, and will be of value to the lawyers of that state, in supplying them with the decisions of their courts in advance of the reports."). As has been explained elsewhere, this fact continues to have consequences today:

West divided the country into seven geographic regions: Atlantic, Northeast, Northwest, Pacific, South, Southeast, and Southwest and created a reporter for each region. The way the states are grouped in these reporters sometimes confuses modern researchers. For example, it seems strange that Oklahoma is contained in the Pacific Reporter, while Kentucky is included in the Southwestern Reporter. The groupings do make some sense if the researcher considers the population distribution of the United States in 1872. 
Wests on it 115 ; and the failure of his children to promote his legacy.116 In addition, his profile, already low, has gone even lower since the company's 1990 decision to leave St. Paul117 and its 1996 takeover by the Thomson Corporation, the Toronto information services giant. 118

Whether John would have been put out by the lack of attention is hard to say, although the answer probably is "no." Unlike other 19th century captains of industry, he did not establish any memorials to himself. Thus, no charitable, civic, or cultural institution bears his name. Likewise, his simple grave gives no hint of who he was. It is as if he intended to leave the world as unobtrusively as he entered it. And yet, every day, wherever law is practiced or taught, his remarkable innovations live on.

In thinking about John, two matters particularly stand out. One is the pure randomness of his life. If he had not moved to St. Paul and gotten a sales job with D.D. Merrill, he would not have met the lawyers he did and ended up inventing the case reporter and the digest. It is possible, of course, that someone else might have done these things, but if not, the legal system would have developed along very different lines. 119

William A. Hilyerd, Using the Law Library: A Guide for Educators-Part II: Deciphering Citations \& Other Ways of Locating Court Opinions, 33 J.L \& EDuc. 365, 373 (2004).

115. While the company eventually adopted an anti-nepotism policy, see MARVIN, supra note 16, at 2, it broke it in 1993. See Jim McCartney, Chairman's Son Named President of West Publishing, St. Paul Pioneer Press, July 27, 1993, at 1E (reporting on the appointment of Vance K. Opperman, the son of Dwight D. Opperman).

116. See MARVIN, supra note 16, at 23-24, 29 (discussing how little information he was able to glean from John's family). In contrast, novelist Kay Boyle both publicized-and embellished-her ancestor's role: "My paternal grandfather, Jesse Peyton Boyle, was a lawyer, and the founder of the West Publishing Company in St. Paul." AutHORS TODAY AND YESTERDAY 85 (Stanley J. Kunitz ed., 1933). Boyle's biographers, however, have set the record straight. See Joan Mellen, Kay Boyle: Author of Herself 16 (1994) (explaining that Peyton Boyle was John's partner), and SANDRA WhIPPle SPanier, Kay Boyle: ARTIST AND Activist 6 (1986) (making it clear that Peyton Boyle was one of the company's co-founders).

117. See Dave Beal et al., West Publishing Leaving St. Paul; Will Move 2,100 Workers to Eagan, St. Paul Pioneer Press, July 4, 1990, at 1A. When its efforts to sell its \$12 million building proved fruitless, the company donated the massive edifice to the county, see Larry Millet, West Publishing Gives Riverfront Headquarters to Ramsey County, ST. PAUL PIONEER PrESS, Sept. 25, 1991, at 1A, which reluctantly converted it into a civic complex known as "Government Center West." See Bill McAuliffe, West Becomes Past in St. Paul, Present and Future in Eagan, STAR TRIB. (Minneapolis), Mar. 25, 1992, at 1B. In January 2008, local officials finally found a buyer for the property, and now believe it will return to the tax rolls in the near future. See On the West Publishing Site: Eager, Hopeful and Cautious, ST. Paul PioneEr Press, Feb. 6, 2008, at B8 (explaining that to recoup its $\$ 10$ million investment, the Opus Group plans to erect a condo-hotel and an office tower).

118. For the sale's details, which triggered an antitrust review by the United States Department of Justice, see Iver Peterson, Thomson to Buy Legal Publisher in a \$3.43 Billion Cash Accord, N.Y. Times, Feb. 27, 1996, at D1, and Iver Peterson, West Publishing Purchase by Thomson is Approved, N.Y. Times, June 20, 1996, at D6. See also Mark J. McCabe, Merging West and Thomson: Pro- or Anti-Competitive?, 97 LAW LiBR. J. 423 (2005).

119. For one view of what might have happened had John not come along, see Susan W. Brenner, Of Publication and Precedent: An Inquiry Into the Ethnomethodology of Case Reporting in the American Legal System, 39 DePAuL L. Rev. 461 (1990). Brenner subsequently expanded her thoughts into a book. See SuSAN W. BrenNer, Precedent INFLATION (1992). 
Second, there is the question of how a man who did not go to college, and who was untrained in the law, was able to devise methods that revolutionized legal research and, by extension, legal practice. 120 Why was no judge or lawyer able to see what he saw? Perhaps the answer is that they were not looking, or perhaps it took an outsider to see what the cognoscenti could not.

In the end, it may be, as some have claimed, that John B. West was a man who merely happened to be in the right place at the right time. 121 Even if this is true, the treatment he has received in the decades since his death seems unkind.

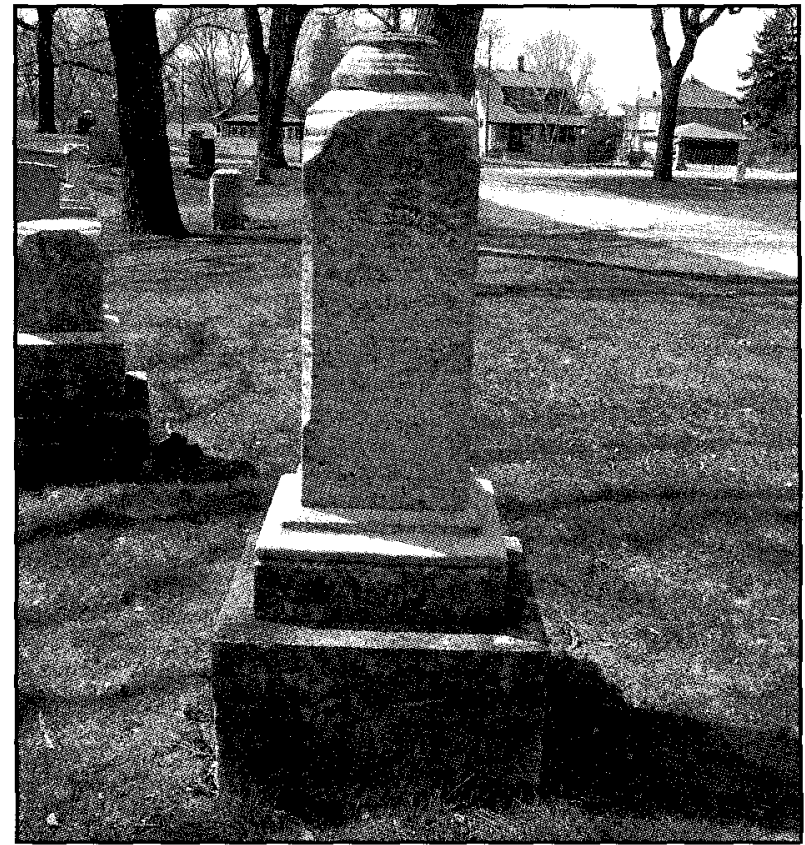

\section{Grave Site of John B. West Oakland Cemetery - St. Paul, Minnesota}

120. Some observers, apparently convinced that a lay person could not have come up with these advances, simply have assumed that John was a lawyer:

Four years later [in 1879], John B. West, a St. Paul, Minnesota lawyer, began a regional reporter of state courts, which eventually multiplied to include all federal and state courts and the famous West digest system. George S. Crossman, Legal Research: Historical FOUNDATIONS OF THE ELECTRONIC AGE 66-69, 76-81 (1994).

James L. Hunt, Thinking Like a Lawyer? Two Southern Law School Exams from the 1870s, 11 J. S. LEGAL HIST. 107, 112 (2003).

121. See, e.g., Joel Howard Cheskis, Copyright of Legal Materials: From Wheaton to West-Shaping the Practice of Law in America, 20 CoMm. \& L. 1, 12 (Sept. 1998) "West's good fortune was due in part to his timing, as his business aggression came after the Industrial Revolution when the American court system was exploding and the need for his services was at its greatest."). 